\title{
Manifestações do conceito de "vazio" no design: desafios metodológicos em pesquisa qualitativa na modalidade de inquérito filosófico
}

\author{
Laura Ueta Bellesa, Luís Cláudio Portugal do Nascimento
}

\author{
estética; design; estética do design; linguagem do design; vazio no \\ design
}

O conceito de "vazio" manifesta-se no design japonês como intervalo espaço-tempo disponível "ma" (OKANO, 2012), adequando objetos de design às necessidades de usuários múltiplos. No campo da estética, a adequação é a essência da beleza dos objetos cotidianos e, portanto, pode estar associada à estética do design. O objetivo desta pesquisa de mestrado consiste em discernir possível associação entre manifestações do conceito de "vazio" na cultura japonesa e ocorrências de "vazio" tanto em projetos de design visual do Estilo Tipográfico Internacional, desenvolvidos na Suíça, na década de 1950, quanto em projetos de design de produto do chamado "estilo Braun", concebidos, a partir da década de 1950, pela equipe de Dieter Rams. 0 método de pesquisa divide-se em cinco etapas. As três primeiras correspondem ao levantamento de dados sobre manifestações do conceito de "vazio" na cultura japonesa, no Estilo Tipográfico Internacional e no chamado "estilo Braun". As técnicas de coleta incluem revisão da bibliografia, buscas na internet, buscas em bancos de dados de trabalhos científicos e análises observacionais de projetos notáveis de design. As duas últimas etapas correspondem ao tratamento de dados da pesquisa, cotejando os resultados da primeira com os da segunda e da terceira etapa. Atualmente, a pesquisadora encontra-se coletando dados da primeira etapa. Por se tratar de um inquérito filosófico, com acentuado caráter histórico, os desafios identificados encontramse, sobretudo, na análise observacional de projetos clássicos de design. Por outro lado, as novas ferramentas de comunicação online, popularizadas durante a pandemia, poderão facilitar o acesso a especialistas que têm observações a contribuir quanto à ocorrência de "vazio" nos projetos de design já mencionados.

\section{Luís Cláudio Portugal \\ do Nascimento}

Professor da Fau-usp, doutor em ensino do design pela New York University (1997), mestre pela École Nationale Supérieure d'Arts et Métiers, Paris (1987), e bacharel em desenho industrial e comunicação visual pela Escola Superior de Desenho Industrial da Uerj (1983).

e-mail: claudioportugal@usp.br

Lattes: http://lattes.cnpq. br/2797773827825547

Orcid: https://orcid.org/00000003-4586-1747 


\title{
Manifestations of the concept of "emptiness" in design: methodological challenges in qualitative research in the form of philosophical inquiry
}

Laura Ueta Bellesa, Luís Cláudio Portugal do Nascimento

\author{
aesthetics; design; design aesthetics; design language; emptiness in \\ design
}

The concept of "emptiness" manifests itself in Japanese design as an available space-time interval "ma" (OKANO, 2012), adapting design objects to the needs of multiple users. In the field of aesthetics, adequacy is the essence of the beauty of everyday objects and, therefore, can be associated with the aesthetics of design. The objective of this master's research is to discern a possible association between manifestations of the concept of "emptiness" in Japanese culture and occurrences of "emptiness" both in visual design projects of the International Typographic Style, developed in Switzerland, in the 1950s, and in product design projects of the so-called "Braun style", conceived, from the 1950s, by the team of Dieter Rams. The research method is divided into five stages. The first three correspond to the data collection about manifestations of the concept of "emptiness" in Japanese culture, in the International Typographic Style and in the so-called "Braun style". Collection techniques include reviewing the bibliography, searching the internet, searching databases of scientific papers, and observational analysis of notable design projects. The last two stages correspond to the treatment of research data, comparing the results of the first with those of the second and third stages. Currently, the researcher is collecting data from the first stage. As this is a philosophical inquiry, with a strong historical feature, the challenges identified are found, above all, in the observational analysis of classic design projects. On the other hand, the new online communication tools, popularized during the pandemic, may facilitate access to specialists who have observations to contribute regarding the occurrences of "emptiness" in the aforementioned design projects.

\section{Referências | References}

\section{do Nascimento}

Professor at Fau-usp. He holds a Ph.D. in art education from New York University (1997), a Masters Degree from École Nationale Supérieure d'Arts et Métiers, Paris (1987), and a Bachelors Degree in Graphic and Industrial Design from Uerj's Escola Superior de Desenho Industrial (1983).

e-mail: claudioportugal@usp.br

Lattes: http://lattes.cnpq. br/2797773827825547

Orcid: https://orcid.org/00000003-4586-1747

OKANO, M. 2012. Ma: entre espaço da arte e comunicação no Japão. São Paulo: Annablume. 